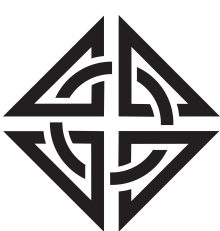

SCIENTIA
Sharif University of Technology

Scientia Iranica

Transactions C: Chemistry and Chemical Engineering

http://scientiairanica.sharif.edu

\title{
Activated nanoporous carbon from walnut shell as a promising adsorbent for methane storage in adsorbed natural gas technology
}

\author{
A. Nouralishahi ${ }^{a}{ }^{*}$, M. Bahaeddini ${ }^{a}$, A. Rashidi ${ }^{b}$, Sh. Mahinnezhad $^{a}$, and A. Fazeli ${ }^{a}$ \\ a. Energy, Environment \& Nanostructure Material Laboratory, Caspian Faculty of Engineering, College of Engineering, University \\ of Tehran, P.O. Box 4386156387, Iran. \\ b. Nanotechnology Research Center, Research Institute of Petroleum Industry (RIPI), Tehran, P.O. Box 14665-1998, Iran.
}

Received 17 September 2018; received in revised form 9 July 2019; accepted 14 September 2019

\section{KEYWORDS}

ANG;

Activated carbon;

Methane;

Nano-porous

adsorbents;

Wallnut shell.

\begin{abstract}
Activated carbon from walnut shell is studied for methane storage in this research. The samples are synthesized by zinc chloride and phosphoric acid as activating agents. The effect of physical activation, after chemical activation steps, on the final structure of the samples and their total methane storage is examined. The results show that physical activation has an improving effect on the total capacity of the samples activated by phosphoric acid; however, it has the opposite effect on the capacity of the samples activated by zinc chloride. The experimental data show that the best capacity is obtained at impregnation ratios of 0.7 and 1.2 in the case of phosphoric acid and zinc chloride activated samples, respectively. The best sample is the one activated by phosphoric acid with an impregnation ratio of 0.7 and, subsequently, physically activated by carbon dioxide. It has a BET surface area of $1479 \mathrm{~m}^{2} / \mathrm{g}$, an average pore diameter of $4.2 \mathrm{~nm}$, the total pore volume of $0.84 \mathrm{~cm}^{3} / \mathrm{g}$, and the methane adsorption capacity of $159 \mathrm{~cm}^{3} / \mathrm{g}$. The sample shows high stability during successive adsorption/desorption cycles experiment.
\end{abstract}

(C) 2019 Sharif University of Technology. All rights reserved.

\section{Introduction}

In recent decades, natural gas, which is mainly made up of methane $\left(\mathrm{CH}_{4}\right)$, has gradually turned to be one of the most important energy carriers due to its high energy value, low emission, high environmental compatibility, and widely distributed reservoirs [1,2]. Due to the huge capacity of Iranian oil and gas reservoirs, there is high potential for using natural gas as a clean and affordable energy carrier in the automotive sector in Iran. There are three different technologies for

\footnotetext{
*. Corresponding author. Tel.: +98 1344608061; Fax: +98 1344608600

E-mail address: Nouralishahi@ut.ac.ir (A. Nouralishahi)
}

natural gas storage: Compressed Natural Gas (CNG), Liquefied Natural Gas (LNG), and Adsorbed Natural Gas (ANG) [3-5]. In fact, the first two categories have disadvantages such as the high cost of liquefaction in LNG method and the safety problems due to the large storage pressure required in the CNG. According to these difficulties, the ANG technology has been considered as a promising alternative [6].

The adsorbent is considered as the heart of ANG Technology. The performance of the adsorbents is related to their pores that can be measured by the adsorbent-adsorbate interaction energy. Due to its textural properties such as high micropore volume and large surface area, Activated Carbon (AC) has attracted much attention as one of the most important materials for adsorbing a wide range of gasses from methane to $\mathrm{CO}_{2}$ and $\mathrm{H}_{2}[7-12]$. The analysis of the 
adsorption of natural gas on suitable adsorbents can be carried out through statistical mechanics, adsorption models, and classic theoretical models [13,14].

There are many mineral sources and agricultural wastes that can be used as the precursor of adsorbent such as coal $[15,16]$, olive and cherry stones [17], coconut shell [18], corn cobs [19], almond shell [20,21], palm shell [22-24], rice husk [25], and walnut shell, which are rich sources of carbon. Walnut shell is one of the activated carbon precursors, which is a low-cost and renewable material [26]. Iran is one of the greatest walnut producers in the world; therefore, walnut shell can be one of the best alternatives as a precursor of activated carbon in this country.

Walnut shell activated carbon has been used for several purposes such as removal of $\mathrm{Pb}$ (II) and mercury from water $[27,28]$, benzene adsorption [29], pharmaceutical usages including the aqueous phase adsorption of cephalexin [30], adsorption of cesium from aqueous solution [31], and removal of anionic dye [32]. In this paper, for the first time, walnut shell activated carbon has been investigated for methane adsorption.

To increase the adsorption capacity of different adsorbents and their micropore volume, chemical and physical activation methods can be considered to activate the carbon. These two methods can be used separately or in combination with each other [33].

In the current research work, both of the mentioned methods have been employed to activate the carbon. A part of our material was chemically activated with two different activating agents, i.e., zinc chloride $\left(\mathrm{ZnCl}_{2}\right)$ or phosphoric acid $\left(\mathrm{H}_{3} \mathrm{PO}_{4}\right)$; in addition, the other part was chemically activated at first and, then, physical activation with carbon dioxide $\left(\mathrm{CO}_{2}\right)$ was done.

Since natural gas is mainly composed of methane $\left(\mathrm{CH}_{4}>90 \%\right)$, many studies have been focused on methane adsorption as a clean and efficient energy source instead of multi-component natural gas $[15,16,34,35] . \mathrm{CH}_{4}$ adsorption on activated carbon has been studied by using different sources; Azevedo et al. [36] and Arami-Niya et al. [37] investigated coconut shell and oil palm shell, respectively. In these two pieces of research, initially, raw materials were chemically activated with $\mathrm{ZnCl}_{2}$, followed by physical activation with $\mathrm{CO}_{2}$. The results of Azevedo et al. showed a significant increase in BET (Brunauer-Emmett-Teller) surface area of chemically activated samples after physical treatment, while Arami-Niya et al. reported that physical treatment after chemical treatment caused a decrease in surface area and methane adsorption. These conflicting results may be related to the difference in raw materials. In this article, the question of how physical activation after chemical activation affects the adsorption capacity for walnut shell, which has not been studied elsewhere, will be addressed.

\section{Experimental}

In this research, two kinds of activated carbon, i.e., zinc chloride and phosphoric acid, as the activating agents were produced. At first, walnut shells were crushed and sieved to mesh sizes in the range of 18-35 (0.5$1 \mathrm{~mm}$ ), washed with distilled water, and then dried at $30^{\circ} \mathrm{C}$. Then, shells were divided into two parts and chemically activated with different ratios of $\mathrm{ZnCl}_{2}$ or $\mathrm{H}_{3} \mathrm{PO}_{4}$ to walnut shell. Walnut was supplied from a local market in Tehran, Iran. $\mathrm{ZnCl}_{2}, \mathrm{H}_{3} \mathrm{PO}_{4}$, and $\mathrm{HCl}$ were purchased from Merck.

\subsection{Chemical activation}

In this research, several walnut shell samples were chemically activated by two different chemical activating agents, i.e., $\mathrm{ZnCl}_{2}$ and $\mathrm{H}_{3} \mathrm{PO}_{4}$. Among all samples, the synthesis parameters of those, which led to the best methane adsorption capacity, are summarized in Table 1, where "Z" or "P" denotes the activating agents of zinc chloride or phosphoric acid, respectively. Briefly, Walnut shells were powdered (mesh number between 150 and 170) and blended well with the chemical activating agent at $60^{\circ} \mathrm{C}$ for two hours. Then, the samples were dried in an oven for 12 hours at $100^{\circ} \mathrm{C}$. The resulting black powders were heated up to a certain temperature at a constant rate and remained at this final temperature for several minutes. During the chemical activation procedure, nitrogen passed over the sample as inert gas to prevent uncontrolled oxidation reaction. Finally, the chemically activated samples were rinsed in $50 \mathrm{vol} . \%$ solution of $\mathrm{HCl}$ for at least 2 hours at $60^{\circ} \mathrm{C}$ to remove the impurities; then, the resulting adsorbents were neutralized with distilled water through several washing steps.

\subsection{Physical activation}

To address the effect of physical activation on the final methane adsorption properties, chemically activated samples were processed under an atmosphere containing $10 \% \mathrm{CO}_{2}$ and $90 \% \mathrm{~N}_{2}$ for $5 \mathrm{~h}$ at $900^{\circ} \mathrm{C}$. In Table 1 , "Ph" at the end of sample codes indicates that those samples are further activated physically with $\mathrm{CO}_{2}$.

\subsection{Characterization}

The surface morphologies of the synthesized activated carbons were determined by field emission scanning electron microscopy (FE-SEM, ZEISS, Model SIGMA VP). BET surface area, pore volume, and pore size distribution according to BET and NLDFT theories were obtained using $\mathrm{N}_{2}$ adsorption/desorption at the boiling point of nitrogen. For this purpose, ASAP 2010 instrument (Micromeritics Co. USA) was used. Before performing the BET tests, samples were degassed at $150^{\circ} \mathrm{C}$ in the vacuum condition. 
Table 1. Synthesis conditions of activated carbons.

\begin{tabular}{|c|c|c|c|c|c|c|}
\hline $\begin{array}{c}\text { Sample } \\
\text { codes }\end{array}$ & $\mathrm{ZnCl}_{2} / \mathrm{WS}^{*}$ & $\mathrm{H}_{3} \mathrm{PO}_{4} / \mathrm{WS}$ & $\begin{array}{c}\text { Physical } \\
\text { activation } \\
\text { temperature }\end{array}$ & $\begin{array}{c}\text { Temperature } \\
\text { scan rate } \\
\left({ }^{\circ} \mathrm{C} / \mathrm{min}\right)\end{array}$ & $\begin{array}{c}\text { Physical } \\
\text { activation } \\
\text { time (min) }\end{array}$ & $\begin{array}{l}\text { Physical } \\
\text { activation }\end{array}$ \\
\hline Z1.0 & 1.0 & - & - & - & - & No \\
\hline $\mathrm{Z} 1.2$ & 1.2 & - & - & - & - & No \\
\hline Z1.3 & 1.3 & - & - & - & - & No \\
\hline $\mathrm{Z1.0Ph}$ & 1.0 & - & 550 & 6 & 160 & Yes \\
\hline $\mathrm{Z1.2Ph}$ & 1.2 & - & 550 & 6 & 160 & Yes \\
\hline $\mathrm{Z1.3Ph}$ & 1.3 & - & 550 & 6 & 160 & Yes \\
\hline P0.7 & - & 0.7 & - & - & - & No \\
\hline P0.9 & - & 0.9 & - & - & - & No \\
\hline P1.0 & - & 1.0 & - & - & - & No \\
\hline P0.7Ph & - & 0.7 & 450 & 4 & 55 & Yes \\
\hline P0.9Ph & - & 0.9 & 450 & 4 & 55 & Yes \\
\hline P1.0Ph & - & 1.0 & 450 & 4 & 55 & Yes \\
\hline
\end{tabular}

*WS: Walnut Shell.

\subsection{Methane Adsorption}

To measure the amount of adsorbed methane, a setup was designed, as shown in Figure 1. This apparatus consists of a vacuum pump (ultimate pressure $10^{-4}$ bar), some manual valves, pressure gauge (0-100 bar), high-precision pressure sensor (0.00 bar to 60.00 bar $)$, sample cell ( $12.5 \mathrm{scc})$, and a reference cell $(85 \mathrm{scc})$, in which these cells are placed in a water bath that work at a constant temperature of $25^{\circ} \mathrm{C}$ for all experiments. A determined mass of the sample, approximately $2 \mathrm{~g}$, was put in the sample cell. Before starting the adsorption test, the samples were degassed under the vacuum condition and heated up to $150^{\circ} \mathrm{C}$ during 2.5 hours inside an electric heater. Assuming that helium cannot be adsorbed on the adsorbents, helium was injected to the cell at the first stage to determine dead volumes. Next, the cell was vacuumed and, then, methane was injected into the Gas Storage Tank at desired pressure. The gas flowed into the sample cell, and the pressure was recorded at equilibrium. By using the initial methane and equilibrium pressure of methane

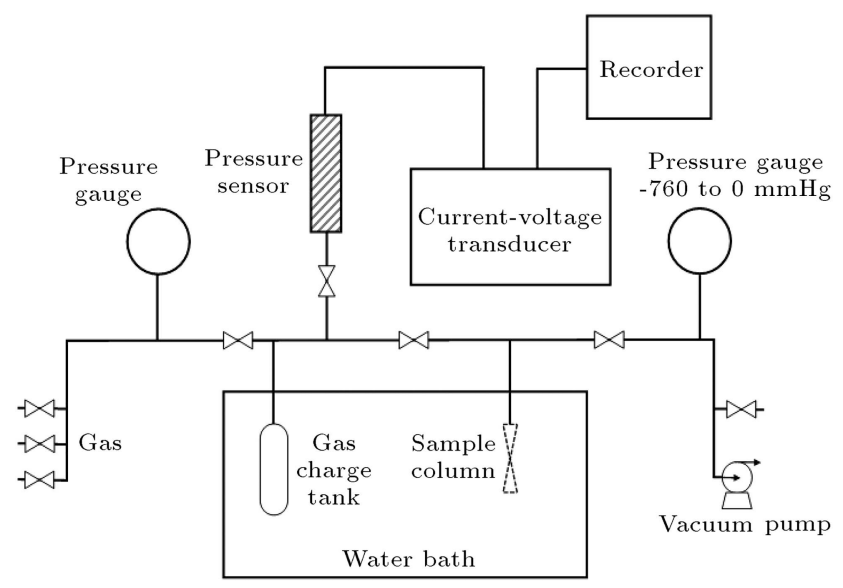

Figure 1. Methane adsorption setup. in the sample cell, the amount of methane adsorbed on the adsorbents can be estimated. By step-wise increasing the pressure from about 5 to 35 bar, methane adsorbate/adsorbent $(\mathrm{ml} / \mathrm{g})$ was measured, plotted as an adsorption isotherm.

\subsection{Cyclic adsorption/desorption}

To study the stability of the adsorption capacity during several cycles, a lab-made setup was assembled according to Figure 2. It can simulate the performance of carbonaceous adsorbents in a cyclic ANG fuel cylinder charging/discharging. In this system, a two-liter cylindrical vessel is filled up with adsorbents firstly, and adsorbent bed temperature is recorded by 13 thermocouples that are set radially. The vessel was put in a water bath, the temperature of which was set to $25^{\circ} \mathrm{C}$. Input and output mass flow of the system is controlled by two mass flow controllers (MFCs, Brooks Ins.). The pressure inside the vessel is recorded by a pressure sensor and transmitted to a computer. To

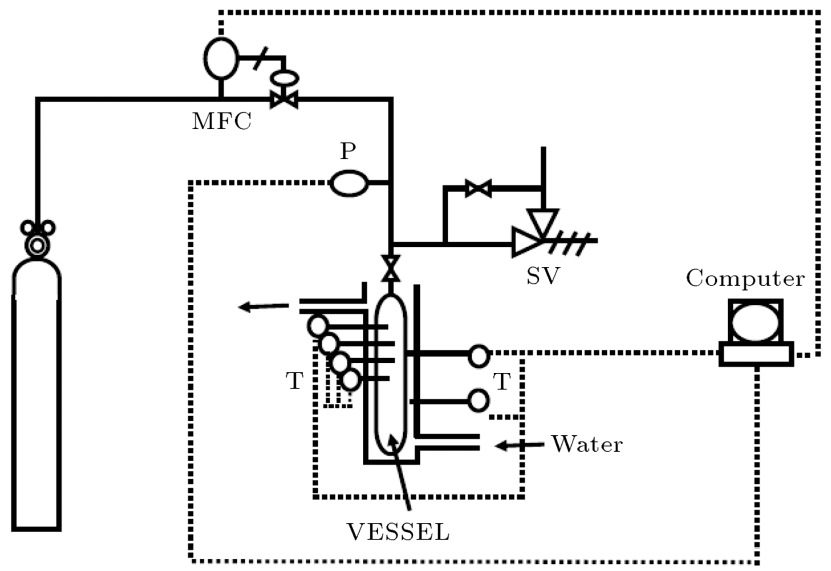

Figure 2. Laboratory system for considering the effect of cycling adsorption/desorption. 


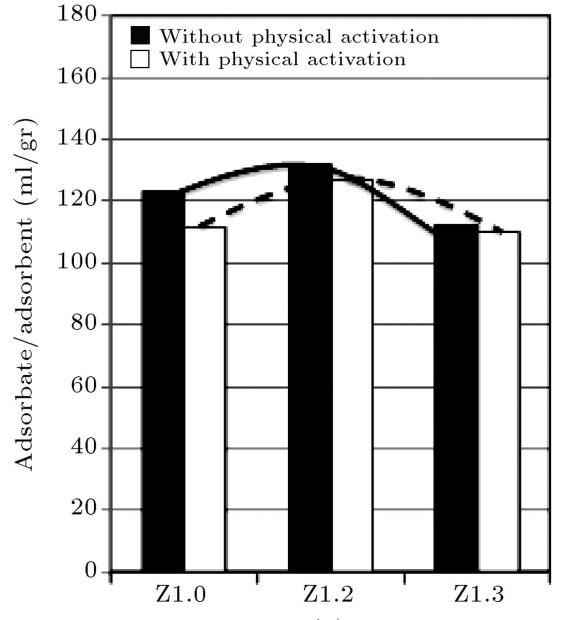

(a)

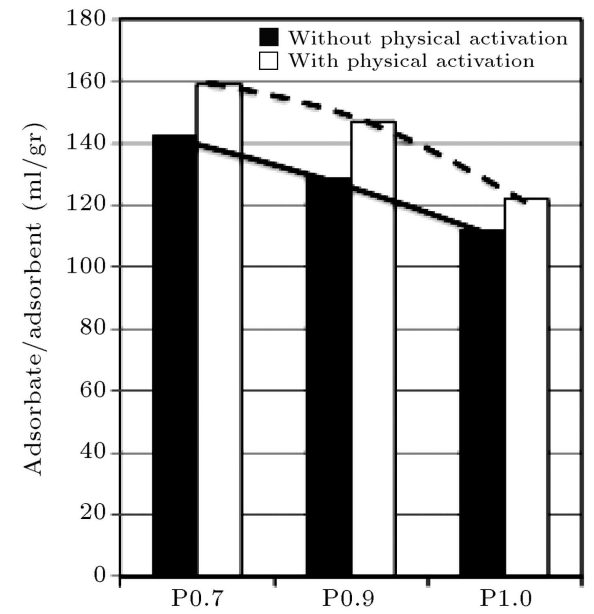

(b)

Figure 3. The effect of the physical activation process on methane adsorption capacities of activated carbon samples at 35 bar: (a) Phosphoric acid activated samples and (b) activated samples.

decrease the risks of the operation, a safety valve adjusted on 40 bar was provided on the vessel to discharge the gas.

At the beginning of the experiment, the vessel was degassed for $2 \mathrm{~h}$ at $150^{\circ} \mathrm{C}$ in a heating mantle and a relative vacuum of -0.95 bar. Then, the vessel, which was located in the isothermal bath at $25^{\circ} \mathrm{C}$, was charged with a gas flow rate of 20 standard liters per minute. This step continued until the pressure of the vessel became 35 bar, and the average difference between vessel and bath temperature was less than $0.5^{\circ} \mathrm{C}$. Vessel discharge operation was performed with a flow rate of 1 standard liter per minute. During each cycle, the temperature and the amount of gas adsorption were recorded by a computer.

\section{Results and discussion}

Methane adsorption capacities at 35 bar are plotted in Figure 3 for all samples shown in Table 1. This bar chart shows a peak for adsorption capacity of the samples activated by $\mathrm{ZnCl}_{2}(\mathrm{Z} 1.0, \mathrm{Z} 1.2$, and $\mathrm{Z} 1.3)$ at different impregnation ratios. This optimum ratio of 1.2 was reiterated for both types of samples, with and without physical activation. This result is in agreement with that of Arami-Niya et al. [37] for oil palm shell. They reported that the micropore volume increased at intermediate $\mathrm{ZnCl}_{2}$ ratios. Figure 3 shows that $\mathrm{Z1.0}$, $\mathrm{Z} 1.2$, and Z1.3 have higher adsorption at 35 bar in comparison to the adsorption status of $\mathrm{Z} 1.0 \mathrm{Ph}, \mathrm{Z} 1.2 \mathrm{Ph}$, and $\mathrm{Z1.3Ph}$. The reduction of this adsorption capacity was more significant at a higher $\mathrm{ZnCl}_{2}$ impregnation ratio. Finally, Z1.2 had the highest adsorption capacity among all the samples activated with $\mathrm{ZnCl}_{2}$.

The samples activated with $\mathrm{H}_{3} \mathrm{PO}_{4}$ had different adsorption capacities at final pressure (i.e., 35 bars), as shown in Figure 3. For P0.7, P0.9, and P1.0 samples, this figure indicates that the adsorption capacity is descending against higher $\mathrm{H}_{3} \mathrm{PO}_{4}$ impregnation ratio, and this pattern was repeated for $\mathrm{P} 0.7 \mathrm{Ph}, \mathrm{P} 0.9 \mathrm{Ph}$, and $\mathrm{P} 1.0 \mathrm{Ph}$ samples. It is implied here that the adsorption capacities of the samples activated by a lower amount of $\mathrm{H}_{3} \mathrm{PO}_{4}$ are remarkably higher than those of the other samples. In this figure, it is obvious that the physically activated samples ( $\mathrm{P} 0.7 \mathrm{Ph}, \mathrm{P} 0.9 \mathrm{Ph}$, and $\mathrm{P} 1.0 \mathrm{Ph}$ ) enjoy higher adsorption capacities than those of P0.7, P0.9, and P1.0 samples, i.e., the combination of chemical and physical activation is more effective in this case.

The optimum impregnation ratio of $\mathrm{H}_{3} \mathrm{PO}_{4}$ in these experiments is 0.7 , which is the lowest one. Eventually, P0.7 is the best sample among all samples, which were just chemically activated by $\mathrm{H}_{3} \mathrm{PO}_{4}$. The sample $\mathrm{P} 0.7 \mathrm{Ph}$ had the highest adsorption capacity among all $\mathrm{P} 0.7 \mathrm{Ph}, \mathrm{P} 0.9 \mathrm{Ph}$, and $\mathrm{P} 1.0 \mathrm{Ph}$ samples and, also, was the best sample among all samples, which were activated by $\mathrm{H}_{3} \mathrm{PO}_{4}$ whether followed by physical activation or not.

The comparison of the samples activated by different agents (i.e., $\mathrm{ZnCl}_{2}$ or $\mathrm{H}_{3} \mathrm{PO}_{4}$ ) in Figure 3 shows that the adsorption capacity of $\mathrm{P} 0.7 \mathrm{Ph}$ is of maximum volume among the capacities of all samples. It is clear that the combination of chemical and physical activation has conflicting effects on the samples activated by $\mathrm{H}_{3} \mathrm{PO}_{4}$ or $\mathrm{ZnCl}_{2}$.

Methane adsorption isotherms for the samples activated by zinc chloride at different impregnation ratios and with/without physical activation are plotted in Figure 4. This figure illustrates that the adsorption capacity is in order of Z1.2>Z1.0 $>\mathrm{Z} 1.3$ at all pressures. Interestingly, the physically treated samples follow the reverse order (i.e., $\mathrm{Z} 1.3 \mathrm{Ph}>\mathrm{Z} 1.0 \mathrm{Ph}>\mathrm{Z} 1.2 \mathrm{Ph}$ ) in the pressure range of $0-35$ bar. This phenomenon suggests a kind of complicated effects of physical activation process on the physicochemical properties of $\mathrm{ZnCl}_{2}$ 


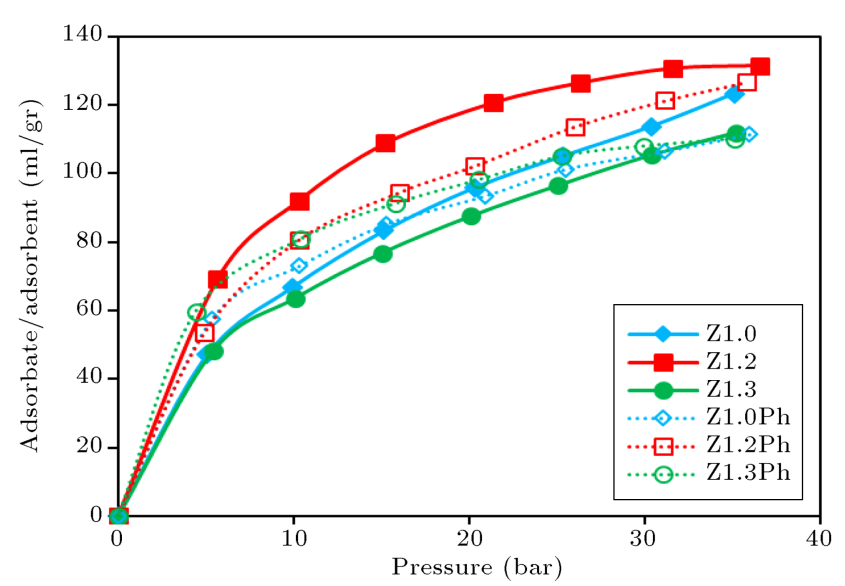

Figure 4. Methane adsorption isotherms of the samples activated by $\mathrm{ZnCl}_{2}$.

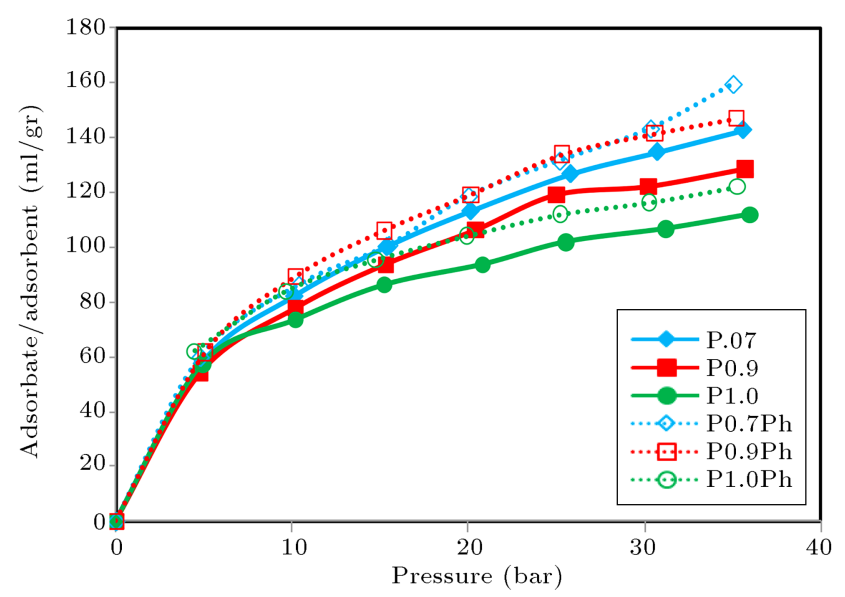

Figure 5. Methane adsorption isotherms of the samples activated by $\mathrm{H}_{3} \mathrm{PO}_{4}$.

chemical activated samples, which can be interpreted as unfavorable changes in pore size distribution, surface affinity with $\mathrm{CH}_{4}$ molecules, or both. Finally, Z1.2 curve is upper than other curves, which proves the higher adsorption capacity of this sample.

Figure 5 illustrates the methane adsorption isotherm for the samples treated by phosphoric acid by changing the impregnation ratios and combining chemical and physical activation in series. It can be concluded from this figure that physical activation increases the volume of adsorbate per mass of adsorbent at all pressures. Adsorption order of $\mathrm{P} 0.7>\mathrm{P} 0.9>\mathrm{P} 1.0$ is revealed in this figure.
FESEM images were used to examine the morphology of synthesized samples. FESEM images of $\mathrm{P} 0.7, \mathrm{P} 0.7 \mathrm{Ph}, \mathrm{Z} 1.2$, and $\mathrm{Z} 1.2 \mathrm{Ph}$ are demonstrated in Figure 6(a)-(d), respectively. It is demonstrated that the surface of the chemically activated samples, i.e., P0.7 and Z1.2, is full of mesopores and defects (Figure $6(\mathrm{a})$ and $6(\mathrm{~b}))$. The cavities result from the corrosion reaction of walnut shell and activation agents during the chemical activation process in which the pristine structure of Walnut shell is partially destructed. Furthermore, physical activation by $\mathrm{CO}_{2}$ enhanced the cavities in terms of both size and number within the carbon matrix (Figures 6(c) and 6(d)), confirming the oxidation reaction between $\mathrm{CO}_{2}$ and carbon at elevated temperatures.

Nitrogen adsorption/desorption isotherms at the boiling point of $\mathrm{N}_{2}$ are shown in Figure 7 for the best samples of each activating agent. The $\mathrm{N}_{2}$ isotherm of $\mathrm{P} 0.7$ sample is upper than those of $\mathrm{P} 0.7 \mathrm{Ph}$ and the Z1.2, indicating the highest BET surface area of P0.7 sample. P0.7 and $\mathrm{P} 0.7 \mathrm{Ph}$ isotherms show wide hysteresis patterns, compared with that of Z1.2. The two samples $\mathrm{P} 0.7$ and $\mathrm{P} 0.7 \mathrm{Ph}$ have a larger number of mesopores than $\mathrm{Z} 1.2$ that can be due to the presence of a hysteresis loop, leading to capillary condensation. All the three samples of $\mathrm{P} 0.7, \mathrm{P} 0.7 \mathrm{Ph}$, and $\mathrm{Z} 1.2$ have micropores since their adsorption curves are concave down at low $\mathrm{P} / \mathrm{P} 0$. Isotherms of $\mathrm{P} 0.7$ and $\mathrm{P} 0.7 \mathrm{Ph}$ samples are of type IV in IUPAC classification [38] that is for micro and mesoporous solids in which the hysteresis loop proves the existence of mesopores and concave down at low $\mathrm{P} / \mathrm{P} 0$ stands for micropores. Based on de Boer's five types of hysteresis, the obtained curves of these two samples are of type A that suggest the cylindrical pores. The isotherm for Z1.2 is of type I in IUPAC classification, which indicates a Langmuir isotherm that is assigned to microporous solids. Figure 8 shows the pore size distribution of the three mentioned samples based on NLDFT theory. The results confirmed that $\mathrm{P} 0.7$ and $\mathrm{P} 0.7 \mathrm{Ph}$ had many more mesopores than Z1.2. Besides, this figure demonstrates a pore diameter at maximum $\mathrm{dV} / \mathrm{dD}$ around $1 \mathrm{~nm}$ for the three samples. Pore diameter at maximum $\mathrm{dV} / \mathrm{dD}$ for $\mathrm{P} 0.7 \mathrm{Ph}$ is smaller than that for $\mathrm{P} 0.7$, which shows the role of physical activation after chemical activation in this samples.

In Table 2, the BET surface area, pore volume,

Table 2. Surface area, pore volume, pore diameter, and methane adsorption capacity of the best samples at the final pressure.

\begin{tabular}{ccccc}
\hline Sample & $\begin{array}{c}\boldsymbol{S}_{\boldsymbol{B} E \mathbf{T}} \\
\left(\mathbf{m}^{\mathbf{2}} \mathbf{g}\right)\end{array}$ & $\begin{array}{c}\text { Pore volume } \\
\left(\mathbf{c m}^{\mathbf{3}} / \mathbf{g}\right)\end{array}$ & $\begin{array}{c}\text { Pore diameter } \\
\mathbf{m a x}(\mathbf{n m})\end{array}$ & $\begin{array}{c}\mathbf{C H}_{\mathbf{4}} \mathbf{a d s o r b a t e} / \mathbf{a d s o r b e n t} \\
\left(\mathbf{c m}^{\mathbf{3}} \mathbf{/ g}\right) \mathbf{a t} \mathbf{3 5} \mathbf{b a r}\end{array}$ \\
\hline $\mathrm{Z} 1.2$ & 1496 & 0.73 & 1.0 & 130 \\
$\mathrm{P} 0.7$ & 1832 & 1.27 & 1.3 & 142 \\
$\mathrm{P} 0.7 \mathrm{Ph}$ & 1479 & 1.00 & 1.0 & 159 \\
\hline
\end{tabular}




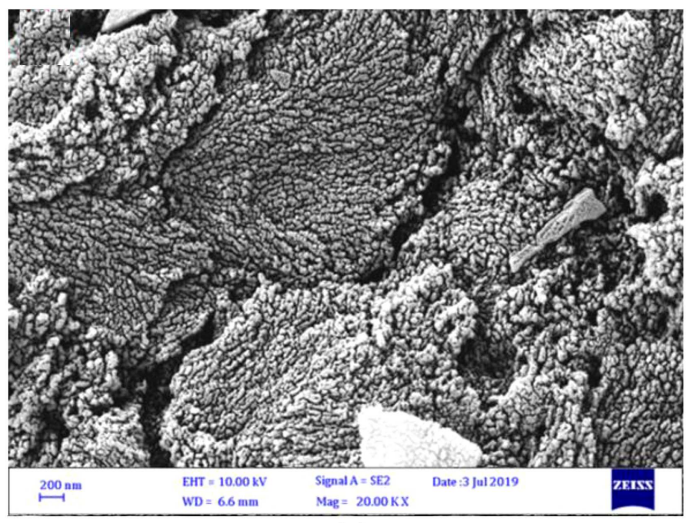

(a)

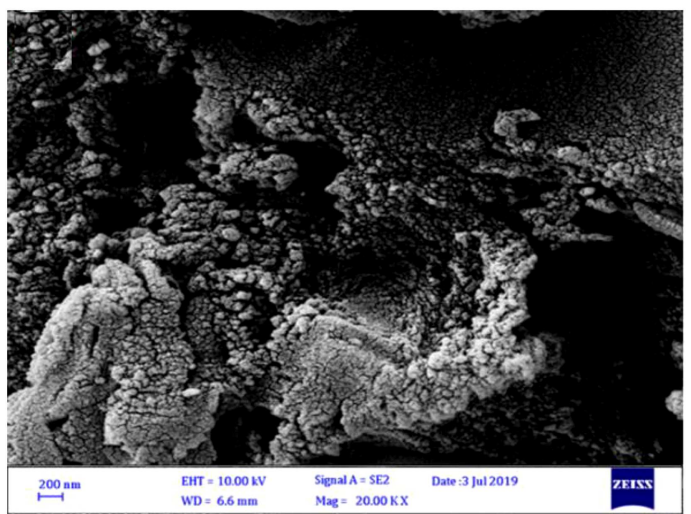

(c)

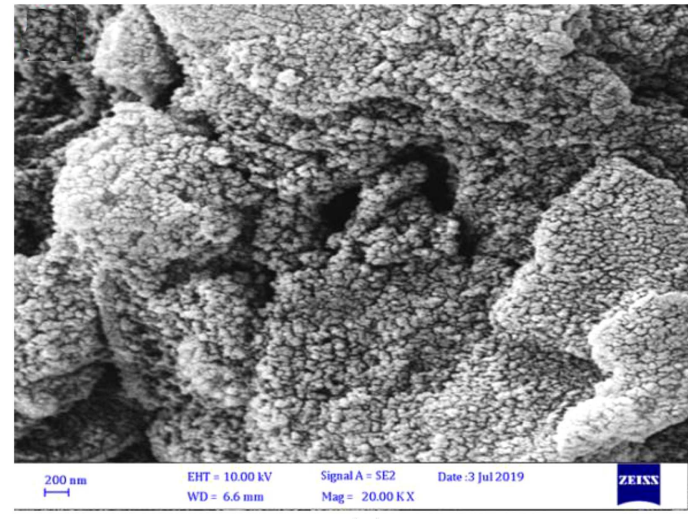

(b)

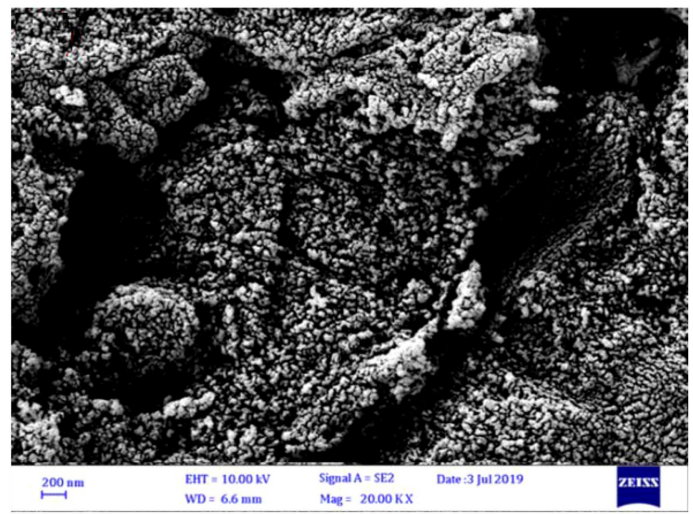

(d)

Figure 6. FE-SEM micrographs of the synthesized activated carbons: (a) P0.7, (b) Z1.2, (c) P0.7Ph, and (d) Z1.2Ph.

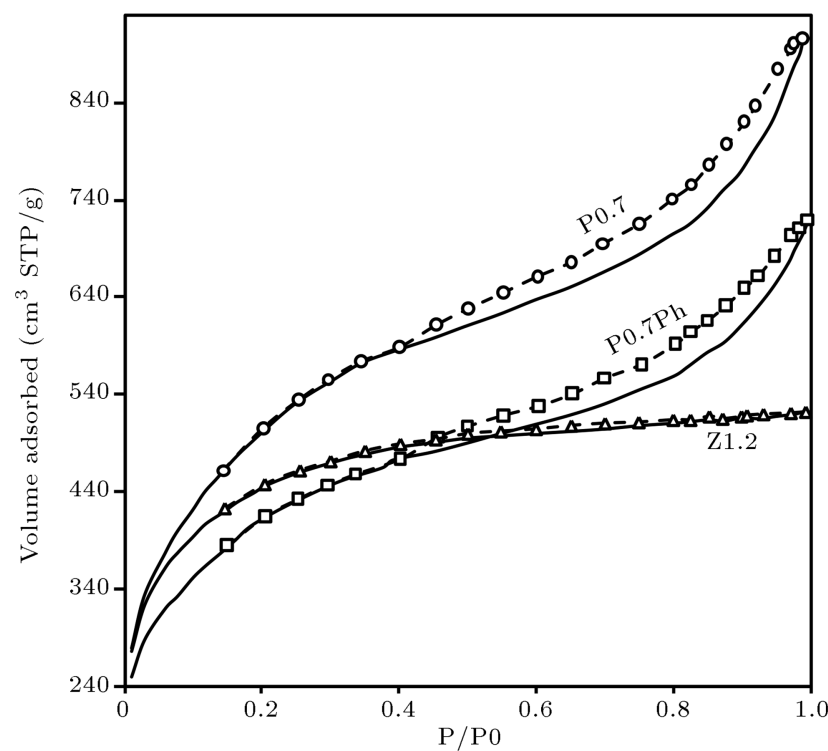

Figure 7. $\mathrm{N}_{2}$ adsorption/desorption isotherms of the best samples at $77 \mathrm{~K}$.

and pore diameter along with the methane adsorption capacity at 35 bar are summarized. The data of Z1.2 and P0.7 samples represent the synergy of the BET surface area, pore volume, and adsorption capacity, i.e., changes in these three parameters are in the

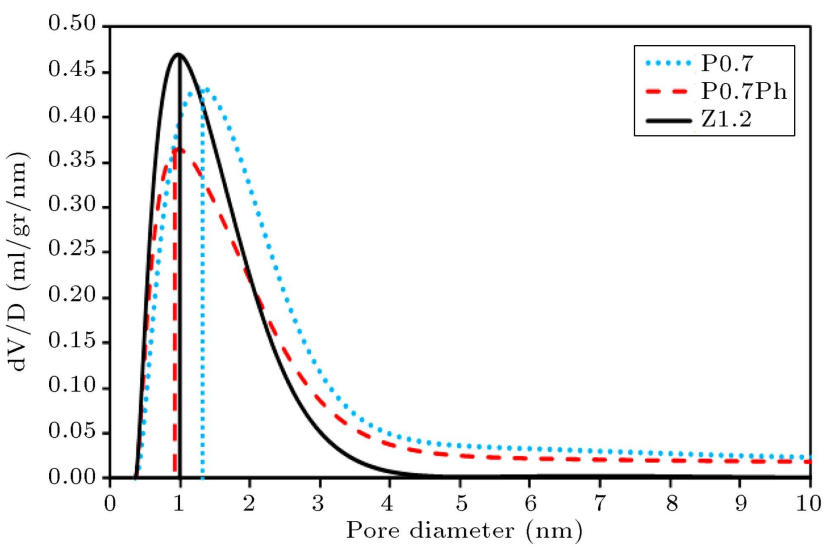

Figure 8. Pore size distribution of the best samples.

same direction. The effect of BET surface area on the adsorption capacity of these two samples is more significant than that of the pore volume.

Even though P0.7 has the highest BET surface area and pore volume, sample $\mathrm{P} 0.7 \mathrm{Ph}$ exhibits the best $\mathrm{CH}_{4}$ adsorption capacity because of a lower micropore diameter. Other parameters, such as surface affinity, may have roles in the adsorption of methane. In fact, physical activation step by $\mathrm{CO}_{2}$ may introduce chemisorbed oxygen groups on the surface [39], which can strengthen the interaction between methane 


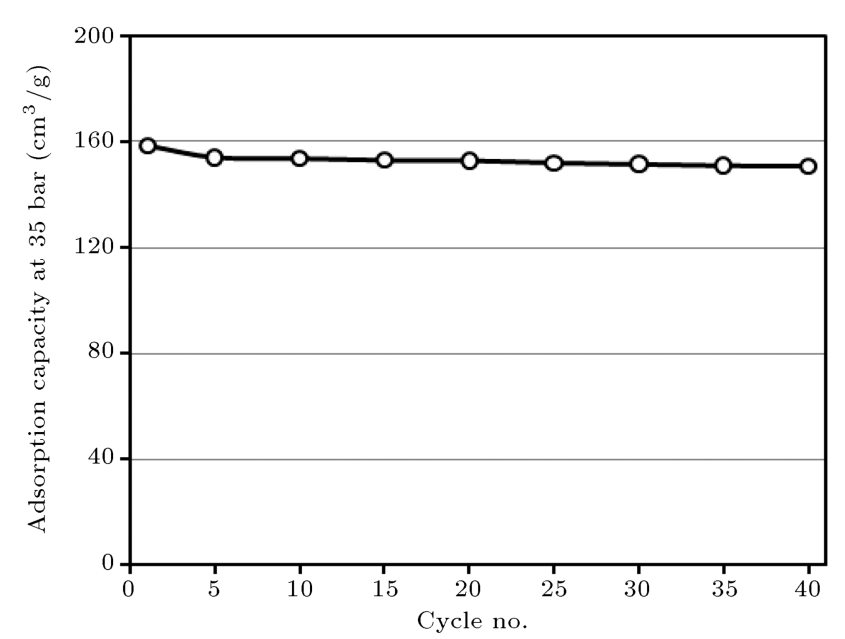

Figure 9. Stability of $\mathrm{P} 0.7 \mathrm{Ph}$ sample during 40 adsorption/desorption cycles.

molecules and adsorbent [40]. These data suggest that the adsorption capacity may be affected by not only the morphological structures but also the oxygen functional groups over the surface of the treated activated carbon.

The results of cyclic adsorption/desorption of the best sample $(\mathrm{P} 0.7 \mathrm{Ph})$ are shown in Figure 9 . According to this figure, adsorbent capacity dropped sharply in the first 5 cycles and, then, became almost stable with a very gradual decrease until the 40th adsorption/desorption cycle. A decrease in the adsorption capacity can be explained by the possible capillary condensation of vapor and/or other heavy molecules presented in the feed (in the form of impurity).

\section{Conclusion}

In this research, several samples of activated carbon were synthesized from walnut shell to be used as an adsorbent for methane storage. The samples were activated chemically using two different materials including zinc chloride and phosphoric acid and, subsequently, were further treated under carbon dioxide atmosphere. The $\mathrm{N}_{2}$ adsorption/desorption isotherms of the samples prepared by optimum activation ratios (i.e., $\mathrm{P} 0.7, \mathrm{P} 0.7 \mathrm{Ph}$, and $\mathrm{Z} 1.2$ ) showed that $\mathrm{P} 0.7$ and $\mathrm{P} 0.7 \mathrm{Ph}$ samples had a wider hysteretic pattern than that of Z1.2. This finding indicated that the phosphoric acid treated samples had a higher amount of mesopore volume. Typically, for the samples activated by $\mathrm{ZnCl}_{2}$, physical activation slightly decreased the methane adsorption capacity. However, in the case of the samples made of $\mathrm{H}_{3} \mathrm{PO}_{4}$, physical activation with $\mathrm{CO}_{2}$ significantly increased the adsorption capacity. For the best sample (P0.7Ph), the physical activation improved the methane storage capacity from 142 to 159 cc $\mathrm{CH}_{4} / \mathrm{g}$ adsorbent, which represents a \%12 improvement in storage capacity due possibly to the physical activation step.

\section{References}

1. Beckner, M., and Dailly, A. "Adsorbed methane storage for vehicular applications", Applied Energy, 149, pp. 69-74 (2017).

2. Kim, S.Y., Kang, J.H., Kim, S.I., et al. "Extraordinarily large and stable methane delivery of MIL-53 (Al) under LNG-ANG conditions", Chemical Engineering Journal, 365, pp. 242-248 (2019).

3. Kanbur, B.B., Xiang, L.M., Dubey, S., et al. "Cold utilization systems of LNG: a review", Renewable Sustainable Energy Rev, 79, pp. 1171-1188 (2017).

4. Khan, M.I., Yasmin, T., and Shakoor, A. "Technical overview of compressed natural gas $(\mathrm{CNG})$ as a transportation fuel", Renewable Sustainable Energy Rev, $\mathbf{5 1}$ pp. 785-797 (2015).

5. Roszak, E.A., and Chorowski, M. "Exergy analysis of combined simultaneous liquid natural gas vaporization and adsorbed natural gas cooling", Fuel, 111 pp. 755762 (2013).

6. Hayatu, U.S., Noor, S.N., Husna, M.Z., et al. "Methane adsorption on KOH microwave treated porous carbon from sustainable coconut solid waste material", Chemical Engineering Transactions, 61 pp. 1249-1254 (2017).

7. Kumar, A., and Hara, M.J. "High surface area microporous activated carbons prepared from Fox nut (Euryale ferox) shell by zinc chloride activation", Applied Surface Science, 356, pp. 753-761 (2015).

8. Romanos, J.S., Sweany, T., Rash, L., et al. "Engineered porous carbon for high volumetric methane storage", Adsorption Science \& Technology, 32(8), pp. 681-691 (2014).

9. Soodsuansi, C., Kulprathipunja, S., Ratanatawanate, C., et al. "Adsorption of methane and carbon dioxide on activated carbon and ZIF-8 (zeolitic imidazolate framework)", Chemical Engineering Transactions, 70, pp. 1633-1638 (2018).

10. Park, J., Lee, G., Hwang, S., Kim, J., et al. "The effects of methane storage capacity using upgraded activated carbon by KOH", Applied Sciences, 8(9), p. 1596 (2018).

11. Kayal, S., and Chakraborty, A. "Activated carbon (type maxsorb-III) and MIL-101 (Cr) metal organic framework based composite adsorbent for higher $\mathrm{CH}_{4}$ storage and $\mathrm{CO}_{2}$ capture", Chemical Engineering Journal, 334, pp. 780-788 (2018).

12. Gao, A., Guo, N., Yan, M., et al. "Hierarchical porous carbon activated by $\mathrm{CaCO}_{3}$ from pigskin collagen for $\mathrm{CO}_{2}$ and $\mathrm{H}_{2}$ adsorption", Microporous and Mesoporous Materials, 260, pp. 172-179 (2018).

13. Bagheri, N., and Abedi, J. "Adsorption of methane on corn cobs based activated carbon", Chemical Engineering Research and Design, 89(10) pp. 2038-2043 (2011).

14. Ybyraiymkul, D., and Ng, K.C. "Experimental and numerical analysis of the influence of thermal control 
on adsorption and desorption processes in adsorbed natural gas storage", Eurasian Chemico-Technological Journal, 18(2), pp. 85-91 (2016).

15. Koonaphapdeelert, S., Moran, J., Aggarangsi, P., et al. "Low pressure biomethane gas adsorption by activated carbon", Energy for Sustainable Development, 43, pp. 196-202 (2018).

16. Feroldi, M., Neves, A.C., Borba, C.E., et al. "Methane storage in activated carbon at low pressure under different temperatures and flow rates of charge", Journal of Cleaner Production, 172, pp. 921-926 (2018).

17. González-Domínguez, J.M., Alexandre-Franco, M., Fernández-González, C., et al. "Activated carbon from cherry stones by chemical activation: Influence of the impregnation method on porous structure", Journal of Wood Chemistry and Technology, 37(2), pp. 148-162 (2017).

18. Abdeljaoued, A., Querejeta, N., Durán, I., et al. "Preparation and evaluation of a coconut shell-based activated carbon for $\mathrm{CO}_{2} / \mathrm{CH}_{4}$ separation", Energies, 11(7), pp. 1748-1761 (2018).

19. Tang, S., Yao, C.h., Ruzhen, X., et al. "Preparation of activated carbon from corn cob and its adsorption behavior on Cr (VI) removal", Water Science and Technology, 73(11), pp. 2654-2661 (2016).

20. Yuso, D., Martínez, A., Izquierdo, M.T., et al. "Toluene and n-hexane adsorption and recovery behavior on activated carbons derived from almond shell wastes", Fuel Processing Rechnology, 110, p: 1-7 (2013).

21. Omri, A., Benzina, M., and Ammar, N. "Preparation, modification and industrial application of activated carbon from almond shell", Journal of Industrial and Engineering Chemistry, 19(6), pp. 2092-2099 (2013).

22. Sethupathi, S., Bashir, M.J., Akbar, Z.A., et al. "Biomass-based palm shell activated carbon and palm shell carbon molecular sieve as gas separation adsorbents", Waste Management \& Research, 33(4), pp. 303-312 (2015).

23. Koutcheiko, S., McCracken, T., Kung, J., et al. "Production of activated carbon from athabasca oil sands bitumen", Petroleum Science and Technology, 25(9), pp. 1215-1224 (2007).

24. Lua, A.C. and Guo, J. "Microporous oil-palm-shell activated carbon prepared by physical activation for gas-phase adsorption", Langmuir, 17(22), pp. 71127117 (2001).

25. Li, M.S., Wu, S.C., Peng, Y.H., et al. "Adsorption of volatile organic vapors by activated carbon derived from rice husk under various humidity conditions and its statistical evaluation by linear solvation energy relationships", Separation and Purification Technology, 170, pp. 102-108 (2016).
26. Yu, Q., Li, M., Ning, P., et al. "Preparation and phosphine adsorption of activated carbon prepared from walnut shells by KOH chemical activation", Separation Science and Technology, 49(15), pp. 2366-2375 (2014).

27. Zheng-ji, Y., Yao, J., Kuang, Y., et al. "Removal of Pb (II) by adsorption onto Chinese walnut shell activated carbon", Water Science and Technology, 72(6), pp. 983-989 (2015).

28. Zabihi, M., Ahmadpour, A., and Haghighi Asl, A. "Removal of mercury from water by carbonaceous sorbents derived from walnut shell", Journal of Hazardous Materials, 167(1-3), pp. 230-236 (2009).

29. Mataji, M. and Khoshandam, B. "Benzene adsorption on activated carbon from walnut shell", Chemical Engineering Communications, 201(10), pp. 1294-1313 (2014).

30. Nazari, G., Abolghasemi, H., Esmaieli, M., et al. "Aqueous phase adsorption of cephalexin by walnut shell-based activated carbon: A fixed-bed column study", Applied Surface Science, 375, pp. 144-153 (2016).

31. Ding, D., Zhao, Y., Yang, S., et al. "Adsorption of cesium from aqueous solution using agricultural residueWalnut shell: Equilibrium, kinetic and thermodynamic modeling studies", Water Research, 47(7), pp. 25632571 (2013).

32. Cao, J.S., Lin, J.X., Fang, F., et al. "A new absorbent by modifying walnut shell for the removal of anionic dye: kinetic and thermodynamic studies", Bioresource Technology, 163, pp. 199-205 (2014).

33. Basumatary, R., Dutta, P., Prasad, M., et al. "Thermal modeling of activated carbon based adsorptive natural gas storage system", Carbon, 43(3), pp. 541549 (2005).

34. Feroldi, M., Neves, A.C., Bach, V.R., et al. "Adsorption technology for the storage of natural gas and biomethane from biogas", International Journal of Energy Research, 40(14), pp. 1890-1900 (2016).

35. Zheng, Y., Li, Q., Yuan, C.Q., et al. "Thermodynamic analysis of high-pressure methane adsorption on coal-based activated carbon", Fuel, 230, pp. 172-184 (2018).

36. Azevedo, D.C., Araujo, J.C.S., Bastos-Neto, M., et al. "Microporous activated carbon prepared from coconut shells using chemical activation with zinc chloride", Microporous and Mesoporous Materials, 100(1-3), pp. 361-364 (2007) .

37. Arami-Niya, A., Daud, W.M.A.W., and Mjalli, F.S. "Using granular activated carbon prepared from oil palm shell by $\mathrm{ZnCl}_{2}$ and physical activation for methane adsorption", Journal of Analytical and Applied Pyrolysis, 89(2), pp. 197-203 (2010). 
38. Sing, K.S.W. "Reporting physisorption data for gas/solid systems with special reference to the determination of surface area and porosity (recommendations 1984)", Pure and Applied Chemistry, 57(4), pp. 603619 (1985).

39. Marsh, H. and Rodriguez-Reinonso, F., Activated Carbon, Elsevier Science \& Technology Books, Amsterdam, pp. 89-100 (2006).

40. Lashaki, M.J., Atkinson, J.D., Hashisho, Z., et al. "The role of beaded activated carbon's pore size distribution on heel formation during cyclic adsorption/desorption of organic vapors", Journal of Hazardous Materials, 315, pp. $42-51$ (2016).

\section{Biographies}

Amiddedin Nouralishahi received his MSc and $\mathrm{PhD}$ in Nanotechnology-Chemical Engineering from Tarbiat Moadares University and University of Tehran, respectively. $\mathrm{He}$ is an Assistant Professor at Caspian Faculty of Engineering. His main research interests include preparation and characterization of carbon nanomaterials for energy conversion and storage more specifically in fuel cells, supercapacitors, and solar cells.

Mohsen Bahaeddini received his BSc in Chemical Engineering from University of Tehran in 2018. His main area of research is related to the preparation of nanomaterials for separation technologies.

Alimorad Rashidi received his $\mathrm{MSc}$ and $\mathrm{PhD}$ in Chemical Engineering from University of Tehran. He is currently a Professor at Research Institute of Petroleum Industry (RIPI). His main research interests include various applications of nanomaterials: mainly carbon nanostructures such as CNT, CNF, and graphene. He also works on the preparation, characterization, and evaluation of nanomaterials in chemical engineering.

Shirin Mahinnezhad received her BSc in Chemical Engineering from University of Tehran in 2019. Her research area is of interest related to the synthesis of carbon nanostructures for energy and environment applications.

Ali Fazeli received his $\mathrm{MSc}$ and $\mathrm{PhD}$ in Chemical Engineering from Sharif University and University of Tehran, respectively. $\mathrm{He}$ is currently an Assistant Professor at Caspian Faculty of Engineering. His main research interests include the modeling and simulation of chemical processes and the preparation and characterization of catalysts. 